\title{
Selective Androgen Receptor Modulators (SARMs) as Function Promoting Therapies
}

\author{
Shalender Bhasin, MD and Ravi Jasuja, PhD \\ Section of Endocrinology, Diabetes, and Nutrition, Boston Claude D. Pepper Older Americans \\ Independence Center for Function Promoting Therapies, Boston University School of Medicine
}

\begin{abstract}
Purpose of review-The last decade has witnessed unprecedented discovery effort to develop selective androgen receptor modulators (SARMs) that improve physical function and bone health without adversely affecting the prostate and cardiovascular outcomes. This review describes the historical evolution, the rationale for SARM development, and the mechanisms of testosterone action and SARM selectivity.

Recent Findings-While steroidal SARMs have been around since the 1940s, a number of nonsteroidal SARMs that do not serve as substrates for CYP19 aromatase or $5 \alpha$-reductase, act as full agonists in muscle and bone and as partial agonists in prostate are in development. The differing interactions of steroidal and nonsteroidal compounds with AR contribute to their unique pharmacologic actions. Ligand binding induces specific conformational changes in the ligand binding domain, which could modulate surface topology and protein-protein interactions between $\mathrm{AR}$ and coregulators, resulting in tissue-specific gene regulation. Preclinical studies have demonstrated the ability of SARMs to increase muscle and bone mass in preclinical rodent models with varying degree of prostate sparing. Phase I trials of SARMs in humans have reported modest increments in fat-free mass.
\end{abstract}

Summary-SARMs hold promise as a new class of function promoting anabolic therapies for a number of clinical indications, including functional limitations associated with aging and chronic disease, frailty, cancer cachexia, and osteoporosis.

\section{Keywords}

SARMs; androgens; mechanisms of tissue selectivity; mechanisms of androgen action

\section{INTRODUCTION}

Selective Androgen Receptor Modulators (SARMs) are a class of androgen receptor ligands that bind androgen receptor and display tissue-selective activation of androgenic signaling $(1,2)$. The initial efforts to develop steroidal SARMs, based on modifications of the testosterone molecule, date back to the 1940s. The modern era of nonsteroidal SARMs was unleashed by independent work at Ligand Pharmaceuticals (3-6) and the University of Tennessee $(7,8)$. The scientists at Ligand Pharmaceuticals were the first to develop a series of cyclic quinolinones that had anabolic activity on the skeletal muscle and some degree of tissue selectivity $(3,4,9-13)$. The discovery by Dalton and Miller that aryl propionamides with structural similarities to bicalutamide and hydroxyflutamide could activate ARdependent transcriptional activity provided the early lead for the development of diaryl

Contact Information: Shalender Bhasin, MD, Section of Endocrinology, 670 Albany Street, Second Floor, Boston Medical Center, Boston, MA 02118, Bhasin@bu.edu. 
propionamide class of SARMs $(7,8)$. The decade since these early efforts has witnessed the emergence of a large number of nonsteroidal SARMs from virtually all the major pharmaceutical companies (2). The review will focus on the rationale for SARM development, the molecular basis of androgen action, the mechanistic basis of tissue selectivity, and potential clinical applications for SARMs.

\section{Rationale}

Testosterone, the major ligand for androgen receptor, subserves a variety of physiologic functions in humans (14): it is essential for maintaining sexual function, germ cell development, and accessory sex organs. Testosterone also affects the skeletal muscle, fat, bone, hematopoeisis, coagulation, lipid, protein and carbohydrate metabolism, and psychosexual and cognitive behaviors. Although androgen deficiency in adult men is the most prevalent disorder of AR signaling (15), the major impetus for SARM development has come from the potential anabolic effects of these compounds on the skeletal muscle and bone.

As men and women grow old, they lose skeletal muscle mass, strength and power (16-20), mostly due to the preferential loss of type 2 muscle fibers (21). Age-associated loss of muscle mass and strength increases the risk of falls, fractures, mobility limitation, physical disability and poor quality of life $(19,22)$. Functional decline and dependence in older individuals place a large burden on health care services and costs. In spite of the high prevalence of functional limitations and disability among older individuals, the practicing geriatricians have few therapeutic choices for the treatment of older individuals with functional limitations and physical disability. Similarly, the course of many chronic illnesses, such as chronic obstructive lung disease, end stage renal disease, congestive heart failure, and some types of cancer, is punctuated by loss of muscle mass and physical functional limitations, which contribute independently to symptoms, mobility limitation, and disability. Thus, there is an enormous unmet need for function promoting anabolic therapies that can improve physical function and reduce the burden of disability. Among the various candidate function promoting anabolic therapies that are in development, SARMs are the farthest along the developmental course.

Testosterone supplementation increases skeletal muscle mass and maximal voluntary strength in healthy, androgen-deficient $(23-26)$ and eugonadal young $(27,28)$ and older men (29), and in men with many chronic disorders $(30,31)$. The anabolic effects of testosterone on skeletal muscle mass and strength are related to testosterone dose and its circulating concentrations $(28,29,32,33)$. Thus, the potential to achieve skeletal muscle remodeling and gains in skeletal muscle mass and strength with androgen supplementation is substantial. However, administration of supraphysiologic doses of androgens is associated with high frequency of dose-limiting adverse effects, such as erythrocytosis, leg edema, and prostate events $(29,34)$. Therefore, therapeutic agents such as SARMs that can achieve anabolic effects on the skeletal muscle and bone without the dose-limiting adverse effects associated with testosterone would be attractive as function promoting anabolic therapies $(1,2,6)$. The recognition of these potential opportunities for the development of novel therapies for functional limitations and disability associated with chronic disorders and aging, and osteoporosis has driven the pharmaceutical efforts to develop SARMs.

\section{Achieving Tissue Selectivity}

Two general approaches have historically been used to achieve tissue selectivity of androgen action. The first approach is to develop SARMs with the desired activity profile and tissue selectivity. The second approach is to elucidate the mechanisms of androgen action on the skeletal muscle and the prostate and to identify signaling molecules that are downstream of 
androgen receptor and which activate pathways involved in skeletal muscle hypertrophy, but not the prostate.

\section{SARMs: Structure Activity Relationships}

Structurally, SARMs can be categorized into steroidal and nonsteroidal SARMs. The steroidal SARMs are formed by modifying the chemical structure of testosterone molecule (Figure 1).

It was recognized in the 1940s that 17-alpha alkyl substitution retards the presystemic metabolism of testosterone, extending its half-life and making it orally active. Thus, a number of oral androgens, such as 17-alpha-methyl testosterone, have 17-alpha-alkyl substitution. However, orally administered, 17-alpha alkylated androgens, are potentially hepatotoxic and markedly lower plasma HDL cholesterol.

Removal of the 19-methyl group increases the anabolic activity of testosterone (Figure 1). Thus, 19-nortestosterone has formed the basis of the nandrolone series of molecules. Nandrolone is reduced by 5- $\alpha$ reductase in target tissues to a less potent androgen, dihydronandrolone, but it is less susceptible to aromatization to an estrogen.

7-alpha alkyl substitutions make testosterone less susceptible to 5-alpha reduction and increase its tissue selectivity with respect to the prostate. Thus, 7-alpha methyl, 19nortestosterone has anabolic activity in the levator ani assay, but has lower level of prostate effects. Other molecules in this series with varying alkyl groups have been investigated for their anabolic activity.

Testosterone is cleared rapidly from circulation and has a short half-life. Esterification of the $17-\beta$ hydroxyl group makes the molecule more hydrophobic; the longer the ester side chain, greater the hydrophobicity. When $17-\beta$ hydroxyl esters of testosterone are injected in an oily suspension intramuscularly, they are released slowly from the oil depot into circulation. The slow release of 17- $\beta$ hydroxyl esters from the oil depot extends their duration of action. However, de-esterification of testosterone esters is not rate limiting; the half-life of testosterone enanthate in plasma is not significantly different from that of non-esterified testosterone. Similarly, esterification of nandrolone to form nandrolone decanoate increases its half-life.

Oxandrolone is an oral androgen derived from DHT that has a 17-alpha methyl substituent. The substitution of second carbon with oxygen increases the stability of the 3-keto group and increases its anabolic activity. It does not undergo aromatization to an estrogen.

\section{NONSTEROIDAL SARMs}

Pioneering efforts by scientists at Ligand Pharmaceuticals and the University of Tennessee provided the early foundations of the nonsteroidal SARM discovery. Since then, a number of structural categories of SARM pharmacophores have been explored: aryl-propionamide (GTX, Inc.), bicyclic hydantoin (BMS), quinolinones (Ligand Pharmaceuticals), tetrahydroquinoline analogs (Kaken Pharmaceuticals, Inc.), benizimidazole, imidazolopyrazole, indole, and pyrazoline derivaties (Johnson and Johnson), azasteroidal derivatives (Merck), and aniline, diaryl aniline, and bezoxazepinones derivatives (GSK) (Figure 2). As only a fraction of the discovery research has been published, it is likely that additional structural categories exist. A recent review by Narayanan et al provides an excellent treatise of the SARM structures (2).

Structural modifications of aryl propionamide analogs bicalutamide and hydroxyflutamide led to the discovery of the first generation of SARMs. Compounds S1 and S4 in this series 
bind AR with high affinity, and demonstrate tissue selectivity in the Hershberger assay that utilizes castrated rat model (35-37). In this castrated rat model, both S1 and S4 prevented castration induced atrophy of levator ani muscle, and acted as weak agonists in the prostate $(35,37,38)$. At a dose of $3 \mathrm{mg} / \mathrm{kg} / \mathrm{day}, \mathrm{S} 4$ partially restored the prostate weight to $<20 \%$ of intact, but fully restored the levator ani weight, skeletal muscle strength, bone mineral density, bone strength, and lean body mass, and suppressed LH and FSH $(39,40)$. S4 also prevented ovariectomy-induced bone loss in female rat model of osteoporosis (41). The ability of SARMs to promote both muscle strength and bone mechanical strength constitutes a unique advantage over other therapies for osteoporosis that only increase bone density.

S1 and S4 are partial agonists; thus, in intact male rats (37), S1 and S4 compete with endogenous androgens and act as antagonists in prostate, such SARMs with antagonistic or low intrinsic activity in prostate might be useful in the treatment of BPH or prostate cancer. The suppressive effects of this class of SARMs on gonadotropin secretion in rats suggest potential application for male contraception (37).

The ether linkage and B-ring para-position substitution are critical for agonist activity of aryl propionamide SARMs (35). Based on crystal structures, compounds with ether linkage appear to adapt a more compact conformation than bicalutamide due to formation of an intramolecular $\mathrm{H}$ bond, allowing the B-ring to avoid steric conflict with the side chain of W741 in AR, and potentially explaining the agonist activity (42).

The hydantoin derivatives, developed by the BMS group (43), have an A-ring structure that is similar to that of bicalutamide. The cyano or nitro group of these molecules interacts with Q711 and R752 $(44,45)$. The benzene ring or the naphthyl group, together with the hydantoin ring, overlaps the steroid plane, while the hydantoin ring nitrogen forms $\mathrm{H}$ bond with N705. BMS-564929 binds AR with high affinity and high specificity. BMS-564929 demonstrated anabolic activity in the levator ani muscle, and high degree of tissue selectivity as indicated by a substantially higher ED50 for the prostate. Hydantoin derivatives are potent suppressors of LH. BMS-564929 is orally available in humans, with half life of 8-14 hours. The prolonged half-life of these ligands in rats may explain the lower dose needed to achieve pharmacological effects; differences in in vivo activities of SARMs that share similar binding affinity and in vitro activity may be related to the differences in pharmacokinetics and drug exposure (46).

Hanada et al (47) at Kaken Pharmaceutical Co. reported a series of tetrahydroquinoline derivatives as AR agonists for bone. Although these compounds displayed high AR affinity and strong agonist activity in prostate and levator ani, they demonstrated little selectivity between androgenic and anabolic tissues (47). Significant in vivo pharmacological activity was only observed at high subcutaneous doses $(2,47)$.

Ligand compounds LGD2226 and LGD 2941 that are bicyclic 6-anilino quinolinone derivatices have shown anabolic activity on the levator muscle as well as bone mass and strength, while having little effect on prostate size in a preclinical rodent model $(5,12,13)$. LGD2226 was also shown to maintain male reproductive behavior in the castrated rodent model (5).

The scientists at Johnson and Johnson replaced the propionamide linker with cyclic elements such as pyrazoles, benzimidazoles, indoles, and cyclic propionanilide mimetics (48). Merck scientists have developed a number of 4-azasteroidal derivatives and butanamides (2). Additional compounds have been developed by other pharmaceutical companies, but a detailed discussion of each compound is beyond the scope of this chapter. 


\section{Mechanisms of SARM Tissue Selectivity}

Narayanan et al compared the pathways activated by an aryl propionamide SARM, S-22, with those activated by DHT (49) and found that the S-22 and DHT activated several distinct signaling pathways. S-22 and DHT differed significantly in the recruitment of AR and its coregulators to PSA enhancer. S-22 also differed from DHT in its induction of rapid phosphorylation of several kinases (49). However, the mechanisms that contribute to tissuespecific transcriptional activation and selectivity of biologic effects of SARMs remain poorly understood. Three general hypotheses have been proposed, although these hypotheses are not mutually exclusive. The co-activator hypothesis assumes that the repertoire of co-regulator proteins that associates with the SARM-bound AR differs from that associated with testosterone-bound AR leading to transcriptional activation of a differentially regulated set of genes.

The conformational hypothesis states that functional differences in ligand classes (agonist, antagonist and SARMs) are reflected into conformationally distinct states with distinct thermodynamic partitioning. Ligand binding induces specific conformational changes in the ligand binding domain, which could modulate surface topology and subsequent proteinprotein interactions between AR and other coregulators involved in genomic transcriptional activation or cytosolic proteins involved in nongenomic signaling. Differences in ligandspecific receptor conformation and protein-protein interactions could result in tissue-specific gene regulation, due to potential changes in interactions with ARE, coregulators or transcription factors. Ligand-induced protein-protein interactions contribute to interactions between the amino and carboxyl terminal ends of the AR (i.e., N/C interaction) and coactivator recruitment (50). Both interactions are mediated by the interaction between the AF2 region of AR and the FXXLF or LXXLL binding motifs (51). The hydrophobic groove present in the AF2 region of AR LBD appears to be more favorable for phenylalanine binding, which suggests that the N/C interaction is preferred. Although nonsteroidal SARMbound AR-LBD conformation has not been well characterized, Sathya et al (52) reported that some steroidal SARMs that have agonist activity in vitro induce an activating conformational change without facilitating N/C interactions. These data suggest that ligandspecific conformational change is achievable with synthetic ligands.

Bohl et al (42) reported that bicalutamide adapts a greatly bent conformation in the AR. Although A-ring and amide bond of the bicalutamide molecule overlaps with the steroidal plane, the B-ring of bilcautamide folds away from the plane, pointing to the top of the ligand binding pocket (LBP), which forms a unique structural feature of this class of ligands (42). The A-ring cyano group forms $\mathrm{H}$ bonds with Q711 and R752, similar to the 3-keto group in $5 \alpha$-DHT (42). The chiral hydroxyl group forms H bonds with L704 and N705, mimicking ring $\mathrm{C}$ and the $17 \beta-\mathrm{OH}$ group in $5 \alpha-\mathrm{DHT}$ (42). These $\mathrm{H}$ bonding interactions are critical for high binding affinity. Slight structural modifications can change the ligand from AR antagonist to agonist. Favorable hydrogen bonding between ligand and the T877 side chain, structural features that mimic the 3-keto group of testosterone, and hydrophobic interactions are critical for the ligand to bind with high affinity and stimulate AR action. X-ray crystal structure of S-1 bound AR revealed that W741 side chain is displaced by the B-ring to expand the binding pocket so that the compound orients towards the AF2 region (53). The protein fold of the SARM-bound AR is the same for steroidal and nonsteroidal SARMs (53). It remains unclear how ligand-receptor interaction determines the agonist or antagonist activity of the ligand.

The tissue selectivity of SARMs could also be related to differences in their tissue distribution, potential interactions with $5 \alpha$-reductase or CYP19 aromatase, or tissue-specific expression of coregulators (54). However, autoradiography studies with bicalutamide and hydantoin derivatives (55) showed that they do not preferentially accumulate in anabolic 
tissues. Testosterone actions in some androgenic tissues are amplified by its conversion to $5 \alpha$-DHT (56); nonsteroidal SARMs do not serve as substrates for $5 \alpha$-reductase. Tissue selectivity of SARMs might be related to tissue-specific expression of coregulatory proteins. Similarly, some differences of the actions of SARM from testosterone could be related to the inability of nonsteroidal SARMs to undergo aromatization.

\section{Preclinical and Early Clinical Trials Experience with the First Generation SARMs}

A large number of candidate SARMs have undergone preclinical proof-of-concept and toxicology studies and have made it into phase I and II clinical trials $(1,2)$. Preclinical studies have revealed promising tissue selectivity; however, as much of these data generated by pharmaceutical companies has remained unpublished, comparisons of relative potency and tissue selectivity among different SARMs are difficult to substantiate.

A number of first generation SARMs are now in phase I trials. These compounds are being positioned for early efficacy trials for osteoporosis, frailty, cancer cachexia, and agingassociated functional limitations. Also, SARMs that potently inhibit gonadotropins, but spare the prostate, would be attractive as candidates for male contraception. The use of SARMs for the treatment of androgen deficiency syndromes in men has been proposed; the relative advantages of SARMs over testosterone for this indication are not readily apparent. Many biological functions of testosterone, especially its effects on libido and behavior, bone, and plasma lipids require its aromatization to estrogen; because the currently available SARMs are neither aromatized nor 5-alpha reduced, these compounds would face an uphill regulatory bar for approval as they would be required to show efficacy and safety in many more domains of androgen action than has been required of testosterone formulations.

At the doses that have been tested, the first generation SARMs induce modest gains in lean body mass in healthy volunteers, which are nowhere near the much greater gains in skeletal muscle mass reported with supraphysiological doses of testosterone. The modest gains of 1.0 to $1.5 \mathrm{~kg}$ in fat-free mass with first generation SARMs over 4-6 weeks should be contrasted with the 5-7 kg gains in fat-free mass with 300 and $600 \mathrm{mg}$ doses of testosterone enanthate. However, it is possible that next generation of SARM molecules will have greater potency and selectivity than the first generation SARMs.

\section{Achieving Selectivity by Elucidating Mechanisms of Action}

Another approach for achieving selectivity of action is to elucidate the mechanisms of testosterone's action on the prostate and identify downstream molecules associated with activation of AR signaling in the skeletal muscle, but not the prostate. Through an understanding of these mechanisms, it may be possible to identify candidate molecules that target specific aspects of the AR signaling cascade.

Analyses of muscle biopsies from men treated with graded doses of testosterone have revealed that testosterone administration induces hypertrophy of both type I and type II muscle fibers $(57,58)$; Changes in cross-sectional areas of both type I and II fibers are related to testosterone dose, and with total and free testosterone concentrations (57). However, neither the absolute number nor the relative proportion of type I and Ii fibers changes during testosterone administration.

As muscle satellite cells have been implicated in skeletal muscle hypertrophy and increase in myonuclear number (59), we quantitated satellite cell and myonuclear number by electron microscopy, using direct counting and spatial orientation methods in biopsies of vastus lateralis obtained at baseline and after 20-weeks of treatment with a GnRH agonist and graded doses of testosterone enanthate. The absolute and percent satellite cell number at 20 weeks was significantly greater than baseline in men receiving supraphysiologic doses of 
testosterone (60). The change in satellite cell number correlated with changes in total and free testosterone levels (60). Hence, testosterone-induced muscle fiber hypertrophy is associated with an increase in satellite cell and myonuclear number.

Testosterone and DHT promote the differentiation of multipotent mesenchymal stem cells into myogenic lineage and inhibit their differentiation into adipogenic lineage (61-63). Testosterone also inhibits differentiation of pre-adipocytes into adipocytes $(63,64)$. Others have suggested that testosterone-induced hypertrophy is caused by stimulation of protein synthesis and the inhibition of protein degradation (65-68). Testosterone and DHT promote the association of liganded AR with its co-activator, $\beta$-catenin; this interaction stabilizes $\beta$ catenin, promotes its translocation into the nucleus and association with TCF-4, and transcriptional activation of a number of Wnt-target genes (69). $\beta$-catenin plays an essential role in mediating the effects of testosterone on myogenic differentiation. Testosterone upregulates follistatin expression in vivo and in vitro (69); infusion of recombinant follistatin protein increases muscle mass and decreases fat mass in castrated mice. Testosterone upregulates SMAD 7 and downregulates TGF $\beta$-mediated SMAD signaling and TGF $\beta$ target genes (69). Follistatin inhibits the action of several TGF $\beta$ family members. These studies support the hypothesis that testosterone effects are cross-communicated from Wnt pathway to TGF $\beta$-SMAD pathway through follistatin. Thus, it is possible that candidate molecules such as follistatin that are downstream of $\mathrm{AR}$ and $\beta$-catenin and which mediate testosterone'e effects on the muscle may provide the desired selectivity of anabolic effects. The AR-mediated signaling pathway downstream of $\beta$-catenin may be an attractive reservoir of candidate targets for the development of selective anabolic drugs.

\section{Regulatory Hurdles to SARM Development}

In phase I and II trials, the first generation SARMs have shown significant reductions in HDL cholesterol and SHBG concentrations, and mild transient elevations of AST and ALT. It is not clear whether transaminase elevations reflect first pass hepatic toxicity typical of orally administered androgens or a class effect on AST gene transcription. Similarly, the suppression of HDL cholesterol might reflect the combined effects of oral route of administration and the lack of aromatization. It is possible that a systemic route of administration - transdermal or intramuscular- might attenuate the potential for transaminase elevation and HDLC reductions.

While the regulatory pathway for the approval of drugs for osteoporosis has been well delineated because of precedence set by previously approved drugs, the pathway for approval of function promoting anabolic therapies has not been clearly established. Considerable effort is underway to generate a consensus around indications, efficacy outcomes in pivotal trials, and minimal clinically important differences in key efficacy outcomes; these efforts should facilitate efficacy trials of candidate molecules.

Conclusion-SARMs hold considerable promise as a new class of function promoting anabolic therapies for a variety of clinical indications, such as frailty, functional limitations associated with aging and chronic illnesses, cancer cachexia, and osteoporosis. Although the preclinical data look promising, the efficacy trials of SARMs are just beginning. Further research is needed to elucidate the molecular basis of tissue selectivity, and to achieve greater potency and tissue selectivity.

\section{REFERNCES}

1. Bhasin S, Calof OM, Storer TW, Lee ML, Mazer NA, Jasuja R, Montori VM, Gao W, Dalton JT. Drug insight: Testosterone and selective androgen receptor modulators as anabolic therapies for chronic illness and aging. Nature Clinical Practice Endocrinology \& Metabolism. 2006; 2:146-159. 
*2. Narayanan R, Mohler ML, Bohl CE, Miller DD, Dalton JT. Selective androgen receptor modulators in preclinical and clinical development. Nuclear receptor signaling. 2008; 6:e010. An excellent treatise of SARM chemistry and structure-activity relationships. [PubMed: 19079612]

3. Edwards JP, West SJ, Pooley CL, Marschke KB, Farmer LJ, Jones TK. New nonsteroidal androgen receptor modulators based on 4-(trifluoromethyl)-2(1H)-pyrrolidino[3,2-g] quinolinone. Bioorganic \& medicinal chemistry letters. 1998; 8:745-750. [PubMed: 9871534]

4. Hamann LG, Mani NS, Davis RL, Wang XN, Marschke KB, Jones TK. Discovery of a potent, orally active, nonsteroidal androgen receptor agonist: 4-ethyl-1,2,3,4-tetrahydro-6(trifluoromethyl)-8-pyridono[5,6-g]-quinoline (LG121071). Journal of medicinal chemistry. 1999; 42:210-212. [PubMed: 9925725]

5. Miner JN, Chang W, Chapman MS, Finn PD, Hong MH, Lopez FJ, Marschke KB, Rosen J, Schrader W, Turner R, van Oeveren A, Viveros H, Zhi L, Negro-Vilar A. An orally active selective androgen receptor modulator is efficacious on bone, muscle, and sex function with reduced impact on prostate. Endocrinology. 2007; 148:363-373. [PubMed: 17023534]

6. Negro-Vilar A. Selective androgen receptor modulators (SARMs): a novel approach to androgen therapy for the new millennium. J Clin Endocrinol Metab. 1999; 84:3459-3462. [PubMed: 10522980]

7. Dalton JT, Mukherjee A, Zhu Z, Kirkovsky L, Miller DD. Discovery of nonsteroidal androgens. Biochem Biophys Res Commun. 1998; 244:1-4. [PubMed: 9514878]

8. He Y, Yin D, Perera M, Kirkovsky L, Stourman N, Li W, Dalton JT, Miller DD. Novel nonsteroidal ligands with high binding affinity and potent functional activity for the androgen receptor. European journal of medicinal chemistry. 2002; 37:619-634. [PubMed: 12161060]

9. Higuchi RI, Arienti KL, Lopez FJ, Mani NS, Mais DE, Caferro TR, Long YO, Jones TK, Edwards JP, Zhi L, Schrader WT, Negro-Vilar A, Marschke KB. Novel series of potent, nonsteroidal, selective androgen receptor modulators based on 7H-[1,4]oxazino[3,2-g]quinolin-7-ones. Journal of medicinal chemistry. 2007; 50:2486-2496. [PubMed: 17439112]

10. Martinborough E, Shen Y, Oeveren A, Long YO, Lau TL, Marschke KB, Chang WY, Lopez FJ, Vajda EG, Rix PJ, Viveros OH, Negro-Vilar A, Zhi L. Substituted 6-(1pyrrolidine)quinolin-2(1H)-ones as novel selective androgen receptor modulators. Journal of medicinal chemistry. 2007; 50:5049-5052. [PubMed: 17887661]

11. Rosen J, Negro-Vilar A. Novel, non-steroidal, selective androgen receptor modulators (SARMs) with anabolic activity in bone and muscle and improved safety profile. Journal of musculoskeletal \& neuronal interactions. 2002; 2:222-224. [PubMed: 15758439]

12. van Oeveren A, Motamedi M, Mani NS, Marschke KB, Lopez FJ, Schrader WT, Negro-Vilar A, Zhi L. Discovery of 6-N,N-bis(2,2,2-trifluoroethyl)amino-4-trifluoromethylquinolin-2(1H)-one as a novel selective androgen receptor modulator. Journal of medicinal chemistry. 2006; 49:61436146. [PubMed: 17034117]

13. van Oeveren A, Motamedi M, Martinborough E, Zhao S, Shen Y, West S, Chang W, Kallel A, Marschke KB, Lopez FJ, Negro-Vilar A, Zhi L. Novel selective androgen receptor modulators: SAR studies on 6-bisalkylamino-2-quinolinones. Bioorganic \& medicinal chemistry letters. 2007; 17:1527-1531. [PubMed: 17267219]

14. Bhasin, S. Testicular Disorders. In: Larsen, R.; Kronenberg, H.; Melmed, S.; Polonski, K., editors. Williams' Textbook of Endocrinology. Philadelphia, PA: WB Saunders, Inc; 2007.

15. Bhasin S, Cunningham GR, Hayes FJ, Matsumoto AM, Snyder PJ, Swerdloff RS, Montori VM. Testosterone therapy in adult men with androgen deficiency syndromes: an endocrine society clinical practice guideline. J Clin Endocrinol Metab. 2006; 91:1995-2010. [PubMed: 16720669]

16. Baumgartner RN. Body composition in healthy aging. Annals of the New York Academy of Sciences. 2000; 904:437-448. [PubMed: 10865787]

17. Baumgartner RN, Waters DL, Gallagher D, Morley JE, Garry PJ. Predictors of skeletal muscle mass in elderly men and women. Mech Ageing Dev. 1999; 107:123-136. [PubMed: 10220041]

18. Roy TA, Blackman MR, Harman SM, Tobin JD, Schrager M, Metter EJ. Interrelationships of serum testosterone and free testosterone index with FFM and strength in aging men. Am J Physiol Endocrinol Metab. 2002; 283:E284-294. [PubMed: 12110533] 
19. Melton LJ 3rd, Khosla S, Crowson CS, O’Connor MK, O’Fallon WM, Riggs BL. Epidemiology of sarcopenia. J Am Geriatr Soc. 2000; 48:625-630. [PubMed: 10855597]

20. Bassey EJ, Fiatarone MA, O’Neill EF, Kelly M, Evans WJ, Lipsitz LA. Leg extensor power and functional performance in very old men and women. Clin Sci (Lond). 1992; 82:321-327.

[PubMed: 1312417]

21. Lexell J, Downham D, Sjostrom M. Distribution of different fibre types in human skeletal muscles. A statistical and computational study of the fibre type arrangement in $\mathrm{m}$. vastus lateralis of young, healthy males. Journal of the neurological sciences. 1984; 65:353-365. [PubMed: 6548511]

22. Orwoll E, Lambert LC, Marshall LM, Blank J, Barrett-Connor E, Cauley J, Ensrud K, Cummings SR. Endogenous testosterone levels, physical performance, and fall risk in older men. Arch Intern Med. 2006; 166:2124-2131. [PubMed: 17060543]

23. Bhasin S, Storer TW, Berman N, Yarasheski KE, Clevenger B, Phillips J, Lee WP, Bunnell TJ, Casaburi R. Testosterone replacement increases fat-free mass and muscle size in hypogonadal men. J Clin Endocrinol Metab. 1997; 82:407-413. [PubMed: 9024227]

24. Wang C, Cunningham G, Dobs A, Iranmanesh A, Matsumoto AM, Snyder PJ, Weber T, Berman $\mathrm{N}$, Hull L, Swerdloff RS. Long-term testosterone gel (AndroGel) treatment maintains beneficial effects on sexual function and mood, lean and fat mass, and bone mineral density in hypogonadal men. J Clin Endocrinol Metab. 2004; 89:2085-2098. [PubMed: 15126525]

25. Wang C, Swerdloff RS, Iranmanesh A, Dobs A, Snyder PJ, Cunningham G, Matsumoto AM, Weber T, Berman N. Transdermal testosterone gel improves sexual function, mood, muscle strength, and body composition parameters in hypogonadal men. J Clin Endocrinol Metab. 2000; 85:2839-2853. [PubMed: 10946892]

26. Snyder PJ, Peachey H, Berlin JA, Hannoush P, Haddad G, Dlewati A, Santanna J, Loh L, Lenrow DA, Holmes JH, Kapoor SC, Atkinson LE, Strom BL. Effects of testosterone replacement in hypogonadal men. J Clin Endocrinol Metab. 2000; 85:2670-2677. [PubMed: 10946864]

27. Bhasin S, Storer TW, Berman N, Callegari C, Clevenger B, Phillips J, Bunnell TJ, Tricker R, Shirazi A, Casaburi R. The effects of supraphysiologic doses of testosterone on muscle size and strength in normal men. N Engl J Med. 1996; 335:1-7. [PubMed: 8637535]

28. Bhasin S, Woodhouse L, Casaburi R, Singh AB, Bhasin D, Berman N, Chen X, Yarasheski KE, Magliano L, Dzekov C, Dzekov J, Bross R, Phillips J, Sinha-Hikim I, Shen R, Storer TW. Testosterone dose-response relationships in healthy young men. Am J Physiol Endocrinol Metab. 2001; 281:E1172-1181. [PubMed: 11701431]

29. Bhasin S, Woodhouse L, Casaburi R, Singh AB, Mac RP, Lee M, Yarasheski KE, Sinha-Hikim I, Dzekov C, Dzekov J, Magliano L, Storer TW. Older men are as responsive as young men to the anabolic effects of graded doses of testosterone on the skeletal muscle. J Clin Endocrinol Metab. 2005; 90:678-688. [PubMed: 15562020]

30. Casaburi R, Bhasin S, Cosentino L, Porszasz J, Somfay A, Lewis MI, Fournier M, Storer TW. Effects of testosterone and resistance training in men with chronic obstructive pulmonary disease. Am J Respir Crit Care Med. 2004; 170:870-878. [PubMed: 15271690]

31. Johansen KL, Mulligan K, Schambelan M. Anabolic effects of nandrolone decanoate in patients receiving dialysis: a randomized controlled trial. Jama. 1999; 281:1275-1281. [PubMed: 10208142]

32. Woodhouse LJ, Reisz-Porszasz S, Javanbakht M, Storer TW, Lee M, Zerounian H, Bhasin S. Development of models to predict anabolic response to testosterone administration in healthy young men. Am J Physiol Endocrinol Metab. 2003; 284:E1009-1017. [PubMed: 12517741]

33. Storer TW, Magliano L, Woodhouse L, Lee ML, Dzekov C, Dzekov J, Casaburi R, Bhasin S. Testosterone dose-dependently increases maximal voluntary strength and leg power, but does not affect fatigability or specific tension. J Clin Endocrinol Metab. 2003; 88:1478-1485. [PubMed: 12679426]

34. Calof O, Singh AB, Lee ML, Urban RJ, Kenny AM, Tenover JL, Bhasin S. Adverse events associated with testosterone supplementation of odler men. J Greontol Med Sci. 2005 in press.

35. Yin D, He Y, Perera MA, Hong SS, Marhefka C, Stourman N, Kirkovsky L, Miller DD, Dalton JT. Key structural features of nonsteroidal ligands for binding and activation of the androgen receptor. Mol Pharmacol. 2003; 63:211-223. [PubMed: 12488554] 
36. Yin D, Gao W, Kearbey JD, Xu H, Chung K, He Y, Marhefka CA, Veverka KA, Miller DD, Dalton JT. Pharmacodynamics of selective androgen receptor modulators. J Pharmacol Exp Ther. 2003; 304:1334-1340. [PubMed: 12604714]

37. Gao W, Kearbey JD, Nair VA, Chung K, Parlow AF, Miller DD, Dalton JT. Comparison of the pharmacological effects of a novel selective androgen receptor modulator, the 5alpha-reductase inhibitor finasteride, and the antiandrogen hydroxyflutamide in intact rats: new approach for benign prostate hyperplasia. Endocrinology. 2004; 145:5420-5428. [PubMed: 15308613]

38. Gao W, Reiser PJ, Coss CC, Phelps MA, Kearbey JD, Miller DD, Dalton JT. Selective Androgen Receptor Modulator (SARM) Treatment Improves Muscle Strength and Body Composition, and Prevents Bone Loss in Orchidectomized Rats. Endocrinology. 2005

39. Gao W, Reiser PJ, Coss CC, Phelps MA, Kearbey JD, Miller DD, Dalton JT. Selective androgen receptor modulator treatment improves muscle strength and body composition and prevents bone loss in orchidectomized rats. Endocrinology. 2005; 146:4887-4897. [PubMed: 16099859]

40. Gao, W.; Reiser, PJ.; Kearbey, JD.; Phelps, MA.; Coss, CC.; Miller, DD.; Dalton, JT. Effects of Novel Selective Androgen Receptor Modulator (SARM) on Skeletal Muscle Mass and Strength in Castrated Male Rats. The Endocrine Society; New Orleans: 2004.

41. Kearbey JD, Gao W, Narayanan R, Fisher SJ, Wu D, Miller DD, Dalton JT. Selective Androgen Receptor Modulator (SARM) treatment prevents bone loss and reduces body fat in ovariectomized rats. Pharmaceutical research. 2007; 24:328-335. [PubMed: 17063395]

*42. Bohl CE, Gao W, Miller DD, Bell CE, Dalton JT. Structural basis for antagonism and resistance of bicalutamide in prostate cancer. Proc Natl Acad Sci U S A. 2005; 102:6201-6206. An important paper that describes the structural basis of antagonism of bicalutamide based on the crystal structure. [PubMed: 15833816]

43. Hamann LG, Manfredi MC, Sun C, Krystek SR Jr, Huang Y, Bi Y, Augeri DJ, Wang T, Zou Y, Betebenner DA, Fura A, Seethala R, Golla R, Kuhns JE, Lupisella JA, Darienzo CJ, Custer LL, Price JL, Johnson JM, Biller SA, Zahler R, Ostrowski J. Tandem optimization of target activity and elimination of mutagenic potential in a potent series of $\mathrm{N}$-aryl bicyclic hydantoin-based selective androgen receptor modulators. Bioorganic \& medicinal chemistry letters. 2007; 17:18601864. [PubMed: 17292608]

44. Manfredi MC, Bi Y, Nirschl AA, Sutton JC, Seethala R, Golla R, Beehler BC, Sleph PG, Grover GJ, Ostrowski J, Hamann LG. Synthesis and SAR of tetrahydropyrrolo[1,2-b] [1,2,5]thiadiazol-2(3H)-one 1,1-dioxide analogues as highly potent selective androgen receptor modulators. Bioorganic \& medicinal chemistry letters. 2007; 17:4487-4490. [PubMed: 17574413]

45. Ostrowski J, Kuhns JE, Lupisella JA, Manfredi MC, Beehler BC, Krystek SR Jr, Bi Y, Sun C, Seethala R, Golla R, Sleph PG, Fura A, An Y, Kish KF, Sack JS, Mookhtiar KA, Grover GJ, Hamann LG. Pharmacological and x-ray structural characterization of a novel selective androgen receptor modulator: potent hyperanabolic stimulation of skeletal muscle with hypostimulation of prostate in rats. Endocrinology. 2007; 148:4-12. [PubMed: 17008401]

46. Kim J, Wu D, Hwang DJ, Miller DD, Dalton JT. The para substituent of S-3-(phenoxy)-2hydroxy-2-methyl-N-(4-nitro-3-trifluoromethyl-phenyl)-prop ionamides is a major structural determinant of in vivo disposition and activity of selective androgen receptor modulators. The Journal of pharmacology and experimental therapeutics. 2005; 315:230-239. [PubMed: 15987833]

47. Hanada K, Furuya K, Yamamoto N, Nejishima H, Ichikawa K, Nakamura T, Miyakawa M, Amano S, Sumita Y, Oguro N. Bone anabolic effects of S-40503, a novel nonsteroidal selective androgen receptor modulator (SARM), in rat models of osteoporosis. Biol Pharm Bull. 2003; 26:1563-1569. [PubMed: 14600402]

48. Ng RA, Lanter JC, Alford VC, Allan GF, Sbriscia T, Lundeen SG, Sui Z. Synthesis of potent and tissue-selective androgen receptor modulators (SARMs): 2-(2,2,2)-Trifluoroethyl-benzimidazole scaffold. Bioorganic \& medicinal chemistry letters. 2007; 17:1784-1787. [PubMed: 17197181]

*49. Narayanan R, Coss CC, Yepuru M, Kearbey JD, Miller DD, Dalton JT. Steroidal androgens and nonsteroidal, tissue-selective androgen receptor modulator, $\mathrm{S}-22$, regulate androgen receptor function through distinct genomic and nongenomic signaling pathways. Mol Endocrinol. 2008; 22:2448-2465. This paper showed that DHT and SARMs activate distinct signaling pathways. [PubMed: 18801930] 
50. Masiello D, Chen SY, Xu Y, Verhoeven MC, Choi E, Hollenberg AN, Balk SP. Recruitment of beta-catenin by wild-type or mutant androgen receptors correlates with ligand-stimulated growth of prostate cancer cells. Mol Endocrinol. 2004; 18:2388-2401. [PubMed: 15256534]

51. Song LN, Herrell R, Byers S, Shah S, Wilson EM, Gelmann EP. Beta-catenin binds to the activation function 2 region of the androgen receptor and modulates the effects of the $\mathrm{N}$-terminal domain and TIF2 on ligand-dependent transcription. Mol Cell Biol. 2003; 23:1674-1687. [PubMed: 12588987]

52. Sathya G, Chang CY, Kazmin D, Cook CE, McDonnell DP. Pharmacological uncoupling of androgen receptor-mediated prostate cancer cell proliferation and prostate-specific antigen secretion. Cancer Res. 2003; 63:8029-8036. [PubMed: 14633736]

*53. Bohl CE, Wu Z, Miller DD, Bell CE, Dalton JT. Crystal structure of the T877A human androgen receptor ligand-binding domain complexed to cyproterone acetate provides insight for ligandinduced conformational changes and structure-based drug design. J Biol Chem. 2007; 282:13648-13655. [PubMed: 17311914]

54. Heinlein CA, Chang C. Androgen receptor (AR) coregulators: an overview. Endocr Rev. 2002; 23:175-200. [PubMed: 11943742]

55. Hamann, LG. Discovery and preclinical profile of a highly potent and muscle selective androgen receptor modulator (SARM). 227th National Meeting of the American Chemical Society Medicinal Chemistry Division; 2004.

56. Russell DW, Wilson JD. Steroid 5 alpha-reductase: two genes/two enzymes. Annual review of biochemistry. 1994; 63:25-61.

57. Sinha-Hikim I, Artaza J, Woodhouse L, Gonzalez-Cadavid N, Singh AB, Lee MI, Storer TW, Casaburi R, Shen R, Bhasin S. Testosterone-induced increase in muscle size in healthy young men is associated with muscle fiber hypertrophy. Am J Physiol Endocrinol Metab. 2002; 283:E154164. [PubMed: 12067856]

58. Kadi F, Eriksson A, Holmner S, Thornell LE. Effects of anabolic steroids on the muscle cells of strength-trained athletes. Medicine and science in sports and exercise. 1999; 31:1528-1534. [PubMed: 10589853]

59. Hawke TJ, Garry DJ. Myogenic satellite cells: physiology to molecular biology. J Appl Physiol. 2001; 91:534-551. [PubMed: 11457764]

60. Sinha-Hikim I, Roth SM, Lee MI, Bhasin S. Testosterone-induced muscle hypertrophy is associated with an increase in satellite cell number in healthy, young men. Am J Physiol Endocrinol Metab. 2003; 285:E197-205. [PubMed: 12670837]

*61. Singh R, Artaza JN, Taylor WE, Gonzalez-Cadavid NF, Bhasin S. Androgens stimulate myogenic differentiation and inhibit adipogenesis in $\mathrm{C} 3 \mathrm{H} 10 \mathrm{~T} 1 / 2$ pluripotent cells through an androgen receptor-mediated pathway. Endocrinology. 2003; 144:5081-5088. This paper was the first to report that androgens regulate myogenic differentiation of mesenchymal multipotent cells. [PubMed: 12960001]

62. Bhasin S, Taylor WE, Singh R, Artaza J, Sinha-Hikim I, Jasuja R, Choi H, Gonzalez-Cadavid NF. The mechanisms of androgen effects on body composition: mesenchymal pluripotent cell as the target of androgen action. J Gerontol A Biol Sci Med Sci. 2003; 58:M1103-1110. [PubMed: 14684707]

63. Gupta V, Bhasin S, Guo W, Singh R, Miki R, Chauhan P, Choong K, Tchkonia T, Lebrasseur NK, Flanagan JN, Hamilton JA, Viereck JC, Narula NS, Kirkland JL, Jasuja R. Effects of dihydrotestosterone on differentiation and proliferation of human mesenchymal stem cells and preadipocytes. Molecular and cellular endocrinology. 2008; 296:32-40. [PubMed: 18801408]

64. Singh R, Artaza JN, Taylor WE, Braga M, Yuan X, Gonzalez-Cadavid NF, Bhasin S. Testosterone inhibits adipogenic differentiation in 3T3-L1 cells: nuclear translocation of androgen receptor complex with beta-catenin and T-cell factor 4 may bypass canonical Wnt signaling to downregulate adipogenic transcription factors. Endocrinology. 2006; 147:141-154. [PubMed: 16210377]

65. Brodsky IG, Balagopal P, Nair KS. Effects of testosterone replacement on muscle mass and muscle protein synthesis in hypogonadal men--a clinical research center study. J Clin Endocrinol Metab. 1996; 81:3469-3475. [PubMed: 8855787] 
66. Urban RJ, Bodenburg YH, Gilkison C, Foxworth J, Coggan AR, Wolfe RR, Ferrando A. Testosterone administration to elderly men increases skeletal muscle strength and protein synthesis. Am J Physiol. 1995; 269:E820-826. [PubMed: 7491931]

67. Ferrando AA, Sheffield-Moore M, Paddon-Jones D, Wolfe RR, Urban RJ. Differential anabolic effects of testosterone and amino acid feeding in older men. J Clin Endocrinol Metab. 2003; 88:358-362. [PubMed: 12519877]

68. Ferrando AA, Sheffield-Moore M, Yeckel CW, Gilkison C, Jiang J, Achacosa A, Lieberman SA, Tipton K, Wolfe RR, Urban RJ. Testosterone administration to older men improves muscle function: molecular and physiological mechanisms. Am J Physiol Endocrinol Metab. 2002; 282:E601-607. [PubMed: 11832363]

*69. Singh R, Bhasin S, Braga M, Artaza JN, Pervin S, Taylor WE, Krishnan V, Sinha SK, Rajavashisth TB, Jasuja R. Regulation of Myogenic Differentiation by Androgens: Cross-Talk between Androgen Receptor/\{beta\}-Catenin and Follistatin/TGF-\{beta\} Signaling Pathways. Endocrinology. 2008 This paper describes the important role of beta-catenin/Wnt pathway in mediating the effects of testosterone on myogenic differentiation and the role of follistatin in cross-communicating the signal from Wnt to TGFbeta/SMAD pathway. 


\begin{tabular}{|c|c|c|}
\hline $\begin{array}{l}\text { Structure:Activity } \\
\text { Relationship }\end{array}$ & Compounds & Chemical Structure \\
\hline $\begin{array}{l}\text { Removing } 19 \\
\text { methyl increases } \\
\text { anabolic activity }\end{array}$ & $\begin{array}{l}\text { 19-nor testosterone } \\
\text { (nandrolone) series } \\
\text { of compounds }\end{array}$ & \\
\hline $\begin{array}{l}\text { 17-alpha alkyl } \\
\text { substitutions retard } \\
\text { first-pass } \\
\text { presystemic } \\
\text { metabolism }\end{array}$ & $\begin{array}{l}\text { Many orally active } \\
\text { steroidal androgens } \\
\text { have } 17 \text {-alpha alkyl } \\
\text { substitutions }\end{array}$ & $\mathrm{H}_{3}$ \\
\hline $\begin{array}{l}\text { 7-alpha alkyl } \\
\text { substitutions } \\
\text { increase anabolic } \\
\text { activity }\end{array}$ & $\begin{array}{l}\text { 7-alpha-methyl-19- } \\
\text { nortestosterone }\end{array}$ & 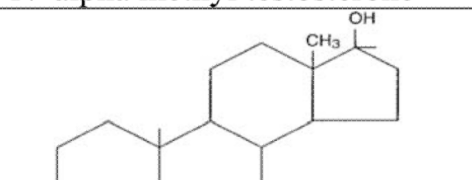 \\
\hline $\begin{array}{l}\text { Esterification of } 17- \\
\text { beta hydroxyl group } \\
\text { increases } \\
\text { hydrophobicity and } \\
\text { extends duration of } \\
\text { in vivo action }\end{array}$ & $\begin{array}{l}\text { Testosterone } \\
\text { enanthate, } \\
\text { cypionate, and } \\
\text { undecanoate }\end{array}$ & Testosterone enanthate \\
\hline
\end{tabular}

Figure 1. Structure: Activity Relationship of Steroidal SARMs

Adapted from Narayanan et al 2008 (2) and Bhasin et al 2006 (1) 


\begin{tabular}{|c|c|c|}
\hline Chemotype & Structure & Examples \\
\hline $\begin{array}{l}\text { Aryl propionamide } \\
\text { analogs }\end{array}$ & & Ostarine, andarine \\
\hline $\begin{array}{l}\text { Bicyclic hydantoin } \\
\text { analogs }\end{array}$ & & BMS 564929 \\
\hline Quinolinones & & LGD2226, LGD2941 \\
\hline $\begin{array}{l}\text { Tetrahydroquinoline } \\
\text { analogs }\end{array}$ & & $\begin{array}{l}\text { Kanen Pharmaceuticals, } \\
\text { S-40503 }\end{array}$ \\
\hline Benzimidazoles & 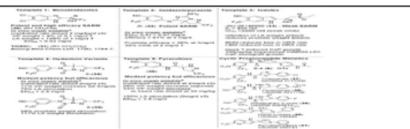 & $\begin{array}{l}\text { Johnson and Johnson's } \\
\text { benzimadozole } \\
\text { derivative }\end{array}$ \\
\hline Butanamides & 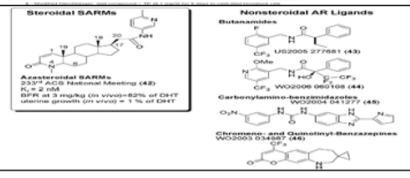 & $\begin{array}{l}\text { Merck SARM based on } \\
\text { butanamide scaffold }\end{array}$ \\
\hline
\end{tabular}

Figure 2. Various Structural Classes of Nonsteroidal SARMs

Adapted from Narayanan et al 2008 (2) and Bhasin et al 2006 (1) 